\title{
Somatic Embryogenesis and Plant Regeneration from Stem, Leaf, and Shoot Apex of Melon (Cucumis melo L.)
}

\author{
Kohji Kageyama,* Kazunori Yabe and Shigetoshi Miyajima \\ Aichi-ken Agricultural Research Center, Aichi-gun, Aichi, 480-11, Japan
}

(Received June 11, 1990)

(Accepted July 12, 1990)

\begin{abstract}
Somatic embryogenesis and plant regeneration were investigated in stem, leaf, and shoot apex culture of melon (Cucumis melo L.). Stems of 3 varieties which had grown in a greenhouse 7-12 weeks after transplanting were cultured on Murashige and Skoog (MS) medium supplemented with 2, 4-dichlorophenoxyacetic acid (2, 4-D), 2-naphthaleneacetic acid (NAA), 6-benzylaminopurine (BA) and casein hydrolysate (CH). Somatic embryos developed from the explants in all tested varieties, but the appropriate concentrations of growth regulators and $\mathrm{CH}$ for somatic embryogenesis were different among the varieties. In leaf and shoot apex culture, the leaves and shoot apexes from aseptic plants of 2 and 11 varieties, respectively, were cultured on MS medium supplemented with 2, 4-D, BA, and sucrose. Somatic embryos developed from the leaf in both tested varieties and from shoot apex in ten tested varieties. Sucrose concentration influenced somatic embryogenesis in these cultures. Plant regeneration was obtained by subculturing somatic embryos derived from stem, leaf, and shoot apex on hormone-free MS medium.
\end{abstract}

Somatic embyogenesis was first reported in carrot by Steward et al. ${ }^{1)}$ Somatic embryos have been derived from various tissues of more than 70 species up to now. ${ }^{2)}$ In Cucurbitaceae, somatic embryogenesis has been investigated in hypocotyl and cotyledon of pumpkin, ${ }^{3,4)}$ in leaf of cucumber, ${ }^{5)}$ and in mature seed of melon. ${ }^{6-8)}$ In melon, plantlets can not readily be induced from somatic embryos.

We are studying micropropagation of melon in order to shorten the breeding cycle of new varieties in cross-breeding. In this case, it is necessary to obtain the explants from plants that have been evaluated to have good-quality fruits, disease resistance, and so on, after harvesting. Therefore, somatic embryo must be derived from stem, leaf, and shoot apex at the ripening stage.

The present paper discusses somatic embryogenesis and plant regeneration from stem, leaf, and shoot apex of different melon varieties.

\section{Materials and Methods}

Stem culture. Three melon varieties, 'Earl's Favourite Haru 1' (Haru 1), 'Earl's Favourite Natsu 1' (Natsu 1), and 'Earl's Favourite Aki 1' (Aki 1), were grown in a greenhouse, and the lateral shoots were cut 7,7 , and 12 weeks after transplanting, respectively. The lateral shoots were surface-sterilized by immersion in $70 \%$ ethanol for $1 \mathrm{~min}$ and $10 \%$ hydrogen peroxide for $30 \mathrm{~min}$, and then rinsed three times with sterilized distilled water. Stems were cut into $5 \mathrm{~cm}$ lengths at approximately $10 \mathrm{~cm}$ from the tip of lateral shoots and were cut horizontally in approximately $2 \mathrm{~mm}$ widths. The explants were cultured on Murashige and Skoog ${ }^{9}$ (MS) medium supplemented with $30 \mathrm{~g} / l$ sucrose, $2 \mathrm{~g} / \mathrm{l}$ Gelrite (Sanei Kagaku Kogyo Co., Osaka), and various combinations of 2, 4-dichlorophenoxyacetic acid (2, 4-D), 2naphthaleneacetic acid (NAA), 6-benzylaminopurine (BA), and casein hydrolysate (CH). For somatic embryogenesis, calli which had been derived from the explants after 6 weeks were transferred to hor-

* Present Address : Laboratory of Plant Pathology, Faculty of Agriculture, Gifu University, Yanagido, Gifu, Gifu 501-11, Japan. 
mone-free MS medium containing $2 \mathrm{~g} / \mathrm{l}$ Gelrite (MS-G medium) and cultured for 4 weeks.

In all experiments in this report, cultures were incubated at $25^{\circ} \mathrm{C}$ under 16 -hr photoperiod (7, 000 lux).

Leaf culture. Seeds of 2 varieties, 'Haru 1' and 'Prince,' were surface-sterilized by immersion in $10 \%$ hydrogen peroxide for $20 \mathrm{~min}$ and then rinsed three times with sterilized distilled water. Sterilized seeds were plated on MS agar medium ( $0.8 \%$ agar). The first and second leaves of 2 -week-old plants were cultured on MS medium supplemented with $2 \mathrm{~g} / \mathrm{l}$ Gelrite and various combinations of 2, 4D, BA, and sucrose for 3 weeks, and were subcultured on the same component medium for 3 weeks. For somatic embryogenesis, calli which had been derived from the explants after 6 weeks were transferred to MS-G medium and cultured for 4 weeks.

Shoot apex culture. Seeds of 11 varieties ('Haru 1,' 'Natsu 7,' 'Aki 1,' 'Earl's Favourite Fuyu 1' (Fuyu 1), 'Atsumi-Earl's,' 'Earl's Tokai R 220,' 'Green Pearl,' 'Andes,' 'Loran,' 'Prince,' and 'Charantes') were surface-sterilized by the same method as leaf culture. Sterilized seeds of 'Green Pearl' and 'Loran' were plated on water agar medium ( $0.8 \%$ agar) and seeds of other varieties were plated on MS agar medium. Approximately $0.5 \mathrm{~mm}$ shoot apexes excised from 1- to 2-week-old plants were cultured on MS medium supplemented with $2 \mathrm{~g} / \mathrm{l}$ Gelrite and various combinations of 2, 4-D, BA, and sucrose. For somatic embryogenesis, calli which had been derived from the explants after 8 weeks were transferred to MS-G medium and were cultured for 4 weeks.

Plant Regeneration. Somatic embryos which developed on the calli in stem, leaf, and shoot apex culture were subcultured on MS-G medium.

\section{Results and Discussion}

\section{Stem culture}

Somatic embryos (1-2 $\mathrm{mm}$ lengths or widths) developed in all 3 tested varieties, but the appropriate medium differed among the varieties (Table 1, Fig. 1 A). Addition of casein hydrolysate $(\mathrm{CH})$ to the medium was effective in 'Haru 1' and 'Aki 1,' but not in 'Natsu 7.' In 'Haru 1,' the number of somatic embryos per callus was more on MS medium containing $1 \mathrm{mg} / \mathrm{l} 2$, $4-\mathrm{D}, 2 \mathrm{mg} / \mathrm{l} \mathrm{NAA}, 0.1 \mathrm{mg} / \mathrm{l}$ $\mathrm{BA}$, and $100 \mathrm{mg} / \mathrm{l} \mathrm{CH}$ than on that containing $1 \mathrm{mg} / l 2,4-\mathrm{D}, 4 \mathrm{mg} / l \mathrm{NAA}$, and $0.1 \mathrm{mg} / / \mathrm{BA}$ without

Table 1. Effect of hormone and casein hydrolysate on callus formation and somatic embryogenesis from stem of melon.

\begin{tabular}{|c|c|c|c|c|c|c|c|c|c|c|c|c|}
\hline \multicolumn{3}{|c|}{ Hormone $(\mathrm{mg} / \mathrm{l})$} & \multirow{2}{*}{$\begin{array}{l}\text { Casein } \\
\text { hydro- } \\
\text { lysate } \\
(\mathrm{mg} / \mathrm{l})\end{array}$} & \multicolumn{3}{|c|}{ Haru 1} & \multicolumn{3}{|c|}{ Natsu 7} & \multicolumn{3}{|c|}{ Aki 1} \\
\hline $2,4-D$ & NAA & BA & & $\begin{array}{l}\text { Callus } \\
\text { forma- } \\
\text { tion } \\
(\%)^{\mathrm{a}}\end{array}$ & $\begin{array}{c}\text { Embryo- } \\
\text { genesis } \\
(\%)^{b}\end{array}$ & $\begin{array}{c}\text { No. of } \\
\text { embryos } \\
\text { per } \\
\text { callus }\end{array}$ & $\begin{array}{l}\text { Callus } \\
\text { forma- } \\
\text { tion } \\
(\%)^{\mathrm{a}}\end{array}$ & $\begin{array}{c}\text { Embryo- } \\
\text { genesis } \\
(\%)^{b}\end{array}$ & $\begin{array}{l}\text { No. of } \\
\text { embryos } \\
\text { per } \\
\text { callus }^{b}\end{array}$ & $\begin{array}{l}\text { Callus } \\
\text { forma- } \\
\text { tion } \\
(\%)^{\mathrm{a}}\end{array}$ & $\begin{array}{c}\text { Embryo- } \\
\text { genesis } \\
(\%)^{\mathrm{b}}\end{array}$ & $\begin{array}{c}\text { No. of } \\
\text { embryos } \\
\text { per } \\
\text { callus }\end{array}$ \\
\hline 1 & 0 & 0.1 & 0 & 100 & 0 & 0 & 100 & 10 & $1(0 / 1)^{c}$ & 10 & 0 & 0 \\
\hline 2 & 0 & 0.1 & 0 & $10 c$ & 0 & 0 & 10 & 0 & 0 & 10 & 0 & 0 \\
\hline 4 & 0 & 0.1 & 0 & 100 & 0 & 0 & 100 & 0 & 0 & 100 & $10^{\mathrm{d}}$ & $2(0 / 0)^{\mathbf{c}}$ \\
\hline \multirow[t]{2}{*}{1} & 1 & 0.1 & 0 & 100 & 0 & 0 & 100 & 10 & $1(1 / 1)$ & 100 & 0 & 0 \\
\hline & & & 100 & 100 & 0 & 0 & 100 & 0 & 0 & 100 & 10 & $1(0 / 1)$ \\
\hline \multirow[t]{2}{*}{1} & 2 & 0.1 & 0 & 100 & 0 & 0 & 100 & 10 & $1(1 / 1)$ & 100 & 0 & 0 \\
\hline & & & 100 & 100 & 10 & $9(2 / 9)^{c}$ & 100 & 0 & 0 & 100 & 10 & $1(0 / 1)$ \\
\hline \multirow[t]{2}{*}{1} & 4 & 0.1 & 0 & 100 & 10 & $1(1 / 1)$ & 100 & 10 & $3(3 / 3)$ & 100 & 0 & 0 \\
\hline & & & 100 & 100 & 0 & 0 & 100 & 0 & 0 & 100 & $11^{\mathrm{d}}$ & $5(0 / 5)$ \\
\hline
\end{tabular}

a 9 to 10 explants were cultured for 6 weeks.

b 10 calli which had been derived from stems were transferred to hormone-free MS medium and cultured for 4 weeks.

c The number of plantlets which were regenerated from somatic embryos by subculturing on hormonefree MS medium.

d Somatic embryos were derived from stems during the incubation on the medium with growth regulators. 
Table 2. Effect of hormone and sucrose on callus formation and somatic embryogenesis from leaf of melon.

\begin{tabular}{|c|c|c|c|c|c|c|c|c|}
\hline \multicolumn{2}{|c|}{ Hormone $(\mathrm{mg} / \mathrm{l})$} & \multirow[b]{2}{*}{$\begin{array}{l}\text { Sucrose } \\
(\mathrm{g} / \mathrm{l})\end{array}$} & \multicolumn{3}{|c|}{ Haru 1} & \multicolumn{3}{|c|}{ Prince } \\
\hline $2,4-\mathrm{D}$ & $\mathrm{BA}$ & & $\begin{array}{c}\text { Callus } \\
\text { formation } \\
(\%)^{\mathrm{a}}\end{array}$ & $\begin{array}{c}\text { Embryogenesis } \\
(\%)^{\mathrm{b}}\end{array}$ & $\begin{array}{c}\text { No. of } \\
\text { embryos } \\
\text { per callus }\end{array}$ & $\begin{array}{c}\text { Callus } \\
\text { formation } \\
(\%)^{a}\end{array}$ & $\begin{array}{c}\text { Embryogenesis } \\
(\%)^{b}\end{array}$ & $\begin{array}{c}\text { No. of } \\
\text { embryos } \\
\text { per callus }\end{array}$ \\
\hline \multirow[t]{2}{*}{1} & 0.1 & 30 & 80 & 0 & 0 & 100 & 0 & 0 \\
\hline & & 70 & 92 & 5 & $1(1 / 1)^{c}$ & 84 & 5 & $5(2 / 5)^{c}$ \\
\hline \multirow[t]{2}{*}{2} & 0.1 & 30 & 96 & 0 & 0 & 100 & 0 & 0 \\
\hline & & 70 & 84 & 5 & $2(1 / 2)$ & 100 & 5 & $1(0 / 1)$ \\
\hline \multirow[t]{2}{*}{4} & 0.1 & 30 & 100 & $5^{\mathrm{d}}$ & $8(4 / 8)$ & 92 & 0 & 0 \\
\hline & & 70 & 100 & 0 & 0 & 100 & 0 & 0 \\
\hline
\end{tabular}

a 25 explants were cultured for 3 weeks.

b 20 calli which had been derived from leaves were transferred to hormone-free MS medium and cultured for 4 weeks.

c The number of plantlets which were regenerated from somatic embryos by subculturing on hormonefree MS medium.

d Somatic embryos were derived from leaves during the incubation on the medium with growth regulators.

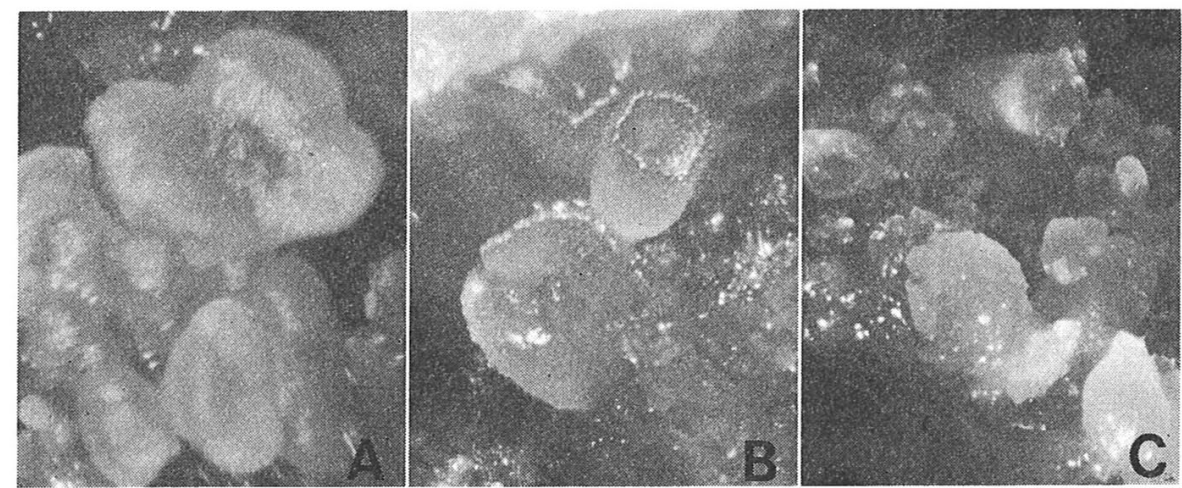

Fig. 1. Somatic embryogenesis from stem (A), leaf (B), and shoot apex (C) of melon.

$\mathrm{CH}$. In 'Aki 1,' somatic embryos were frequently formed on the medium with $\mathrm{CH}$, and also during incubation on the medium with growth regulators.

\section{Leaf culture}

Somatic embryos (1-2 mm lengths or widths) developed in both 'Haru 1' and 'Prince' (Table 2, Fig. 1 B). In 'Haru 1,' sucrose concentration influenced the appropriate 2, 4-D concentration for somatic embryogenesis. High 2, 4-D concentration was appropriate in the medium with $30 \mathrm{~g} / \mathrm{l}$ sucrose and low 2, 4-D concentration was appropriate in the medium with $70 \mathrm{~g} / l$ sucrose. In 'Prince,' no somatic embryo developed on the medium with $30 \mathrm{~g} / l$ sucrose. Somatic embryogenesis was found during incubation on the MS medium supplemented with $4 \mathrm{mg} / / 2,4-\mathrm{D}, 0.1 \mathrm{mg} / / \mathrm{BA}$, and $30 \mathrm{~g} / /$ sucrose in 'Haru 1.'

Tabei et al. ${ }^{10)}$ reported the influence of $2,4-\mathrm{D}$ concentration on somatic embryogenesis. This experiment indicated that the appropriate 2, 4-D concentration for somatic embryogenesis was reflected in the sucrose concentration and somatic embryos were most frequently formed in the medium with $70 \mathrm{~g} / \mathrm{l}$ sucrose.

\section{Shoot apex culture}

Somatic embryos (1-2 mm lengths or widths) developed in 10 varieties except for 'Loran' (Table 3, 
Fig. 1 C). Many somatic embryos were formed after transferring calli from the medium containing growth regulators to hormone-free medium, but in 'Haru 1,' 'Natsu 7,' 'Aki 1,' 'Fuyu 1,' 'Earl's Tokai R 220,' and 'Green Pearl,' several somatic embryos developed in the initial culture medium with callus formation. The influence of 2, 4-D on callus formation and somatic embryogenesis did not differ among tested varieties. On the medium with $4 \mathrm{mg} / / 2,4-\mathrm{D}$, the percentage of callus formation was low and somatic embryos were not obtained in any of the tested varieties. Varietal differences were found in the influence of sucrose on somatic embryogenesis. The 10 varieties in which somatic embryogenesis was found were divided into 3 groups by the reaction to sucrose. (1) The varieties in which $30 \mathrm{~g} / \mathrm{l}$ sucrose enhanced somatic embryogenesis : 'Fuyu 1,' 'Andes,' and 'Prince.' (2) The varieties in which $70 \mathrm{~g} / \mathrm{l}$ sucrose enhanced somatic embryogenesis : 'Haru 1,' 'Earl's Tokai R 220,' and 'Charantes.' (3) The varieties in which somatic embryos were formed regardless of tested sucrose concentrations : 'Natsu 7,' 'Aki 1,' 'Atsumi-Earl's', and 'Green Pearl'. Hayashi' ${ }^{11}$ suggested that the use of a higher sucrose concentration was beneficial for somatic embryogenesis. In the present experiment, the appropriate sucrose concentration was different among the tested varieties.

There were no relationships between the conditions of callus formation and of somatic embryogenesis. Though the percentage of callus formation was high on the medium with $30 \mathrm{~g} / l$ sucrose, no somatic embryos developed in 'Haru 1' and 'Charantes.' In 'Loran,' callus was formed on the medium with $30 \mathrm{~g} / l$ and $70 \mathrm{~g} / l$ sucrose but no somatic embryo developed.

\section{Plant regeneration}

Somatic embryos which were formed in stem, leaf, and shoot apex culture regenerated into plantlets with normal morphogenesis (Tables 1-3, Fig. 2). But several somatic embryos developed only roots,

Table 3. Effect of 2,4-D and sucrose concentrations on callus formation and somatic embryogenesis from shoot apex in 11 cultivars of melon.

\begin{tabular}{|c|c|c|c|c|c|c|c|c|c|c|c|c|}
\hline \multirow[b]{2}{*}{ Cultivar } & \multicolumn{4}{|c|}{$\begin{array}{l}\text { Medium containing } 1 \mathrm{mg} / l \\
2,4-\mathrm{D} \text { and } 30 \mathrm{~g} / l \text { sucrose }\end{array}$} & \multicolumn{4}{|c|}{$\begin{array}{l}\text { Medium containing } 1 \mathrm{mg} / l \\
2,4-\mathrm{D} \text { and } 70 \mathrm{~g} / l \text { sucrose }\end{array}$} & \multicolumn{4}{|c|}{$\begin{array}{l}\text { Medium containing } 4 \mathrm{mg} / l \\
2,4-\mathrm{D} \text { and } 30 \mathrm{~g} / l \text { sucrose }\end{array}$} \\
\hline & $\begin{array}{l}\text { No. of } \\
\text { shoot } \\
\text { apexes }\end{array}$ & $\begin{array}{l}\text { Callus } \\
\text { forma- } \\
\text { tion } \\
(\%)^{a}\end{array}$ & $\begin{array}{c}\text { Embryo- } \\
\text { genesis } \\
(\%)^{b}\end{array}$ & $\begin{array}{c}\text { No. of } \\
\text { somatic } \\
\text { embryos } \\
\text { per } \\
\text { callus a }^{\text {a a }}\end{array}$ & $\begin{array}{l}\text { No. of } \\
\text { shoot } \\
\text { apexes }\end{array}$ & $\begin{array}{l}\text { Callus } \\
\text { forma- } \\
\text { tion } \\
(\%)^{a}\end{array}$ & $\begin{array}{c}\text { Embryo- } \\
\text { genesis } \\
(\%)^{\mathrm{b}}\end{array}$ & $\begin{array}{l}\text { No. of } \\
\text { somatic } \\
\text { embryos } \\
\text { per } \\
\text { callus }^{b}\end{array}$ & $\begin{array}{l}\text { No. of } \\
\text { shoot } \\
\text { apexes }\end{array}$ & $\begin{array}{l}\text { Callus } \\
\text { forma- } \\
\text { tion } \\
(\%)^{a}\end{array}$ & $\begin{array}{c}\text { Embryo- } \\
\text { genesis } \\
(\%)^{b}\end{array}$ & $\begin{array}{l}\text { - No. of } \\
\text { somatic } \\
\text { embryos } \\
\text { per } \\
\text { callus }\end{array}$ \\
\hline \multicolumn{13}{|c|}{ Earl's Favourite } \\
\hline Haru 1 & 10 & 100 & 0 & 0.0 & 41 & 85 & $60^{c}$ & $2.3(3 / 14)^{d}$ & 10 & 30 & 0 & 0.0 \\
\hline Natsu 7 & 10 & 70 & $10^{c}$ & 2. $0(1 / 2)^{d}$ & 20 & 20 & $5^{c}$ & 1. $0(0 / 1)$ & 10 & 40 & 0 & 0.0 \\
\hline Aki 1 & 10 & 70 & $30^{c}$ & 3. $3(5 / 10)$ & 15 & 67 & $20^{c}$ & 3. $3(6 / 10)$ & 10 & 10 & 0 & 0.0 \\
\hline Fuyu 1 & 10 & 80 & 20 & 1. $0(1 / 2)$ & 15 & 60 & $7^{\mathrm{c}}$ & 1. $0(1 / 1)$ & 10 & 20 & 0 & 0.0 \\
\hline Atsumi-Earl's & 10 & 100 & 10 & 2. $0(1 / 2)$ & 19 & 79 & 11 & 1. $0(0 / 2)$ & 10 & 10 & 0 & 0.0 \\
\hline $\begin{array}{r}\text { Earl's Tohkai } \\
\text { R } 220\end{array}$ & 10 & 80 & $30^{c}$ & 5. $3(10 / 16)$ & 15 & 100 & $60^{c}$ & 3. $0(19 / 27)$ & ) 10 & 40 & 0 & 0.0 \\
\hline Green Pearl & 10 & 100 & 10 & 5. $0(1 / 2)$ & 10 & 50 & $10^{c}$ & 10. $O(2 / 10)$ & 10 & 0 & 0 & 0.0 \\
\hline Andes & 10 & 70 & 10 & 1. $0(0 / 1)$ & 10 & 10 & 0 & 0.0 & 10 & 0 & 0 & 0.0 \\
\hline Loran & 10 & 70 & 0 & 0.0 & 10 & 50 & 0 & 0.0 & 4 & 0 & 0 & 0.0 \\
\hline Prince & 10 & 80 & 20 & $2.5(5 / 5)$ & 9 & 56 & 11 & 1. $0(0 / 1)$ & 8 & 25 & 0 & 0.0 \\
\hline Charantes & 9 & 67 & 0 & 0.0 & 10 & 80 & 10 & 7. $0(1 / 7)$ & 10 & 0 & 0 & 0.0 \\
\hline
\end{tabular}

a Shoot apexes were cultured for 8 weeks.

b Calli which had been derived from shoot apexes were transferred to hormone-free MS medium and were cultured for 4 weeks.

c Somatic embryos were derived from shoot apexes during the incubation on the medium with growth regulators.

d The number of plantlets which were regenerated from somatic embryos by subculturing on hormonefree MS medium. 


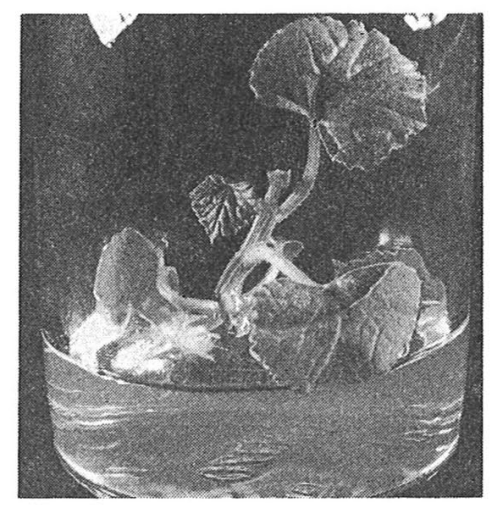

Fig. 2. Plant regeneration from somatic embryo in shoot apex culture of melon.

and plantlets with multiple shoots. Several somatic embryos were expanding without plant regeneration.

From the present study, it was considered possible that somatic embryos were derived from stem, leaf, and shoot apex culture and that somatic embryos developed plantlets. Somatic embryogenesis from stem has never been reported in melon. These culture procedures by which somatic embryos have been induced from stem, leaf, and shoot apex may be applied to micropropagation of melon for shortening the breeding cycle of new varieties.

Somatic embryos were not frequently derived from leaf and stem. With a view to increasing the efficiency of somatic embryo formation, it seemed beneficial to examine the process and the varietal difference of somatic embryogenesis. The process of somatic embryogenesis in melon was found to be different from that in carrot. In carrot, somatic embryo has been derived from callus on the medium without auxin after incubation of the explants on the medium with auxin. ${ }^{12)}$ On the other hand, in melon, somatic embryo developed during incubation on the medium with auxin. Therefore, it is considered that somatic embryogenesis will be affected by the medium condition at an early stage of the induction in melon. The varietal differences in the ability of organogenesis have been reported in tomato, ${ }^{13,14)}$ eggplant, ${ }^{15)}$ Chinese cabbage, ${ }^{16)}$ and cucumber. ${ }^{17)}$ In this experiment the varietal differences were found not only in the ability of somatic embryogenesis but also in the appropriate medium conditions for that. To find the optimum medium conditions for induction and development of the somatic embryogenesis in each different cultivar of melon, further studies are required.

This work was partly supported by a grant from the Ministry of Agriculture, Forestry and Fisheries of Japan.

\section{References}

1) Steward, F. C., M. O. Mapes, K. Mears, 1958. Am. J. Bot., 45 : 705-708.

2) Williams, E. G., G. Maheswaran, 1986. Ann. Bot., 57: 443-462.

3) Jelaska, J., 1972. Planta, 103: 278-280.

4) Jelaska, J., 1974. Physiol. Plant., 31: 257-261.

5) Chee, P. P., D. M. Tricoli, 1988. Plant Cell Rep., 7: 274-277.

6) Oridate, T., K. Oosawa, 1986. Jpn. J. Breed., 36: 424-428.

7) Moreno, V., M. Garcia-Sogo, I. Granel, B. Garcia-Sogo, L. A. Roig, 1985. Plant Tissue Organ Cult., $5:$ 139-146.

8) Trulson, A. J., E. A. Shahin, 1986. Plant Sci., 47: 35-43.

9) Murashige, T., F. Skoog, 1962. Physiol. Plant., 15: 473-497.

10) Tabei, Y., T. Kanno, I. Igarashi, T. Nishio, 1988. Jpn. J. Breed., 38 (suppl. 1): 20-21.

11) Hayashi, E., 1989. Abstracts of Japanese Association for Plant Tissue Culture 11 th Meeting, p. 49. 
12) Fujimura, T., A. Komamine, 1979. Plant Physiol., 64: 162-164.

13) Behki, R. M., S. M. Lesley, 1976. Can. J. Bot., 54 : 2409-2414.

14) Kageyama, K., K. Yabe, S. Miyajima, 1988. Res. Bull. Aichi Agric. Res. Ctr., 20 : 167-171.

15) Sato, T., T. Nishio, M. Hirai, 1989. Jpn. J. Breed., 39 : 149-157.

16) Kim, S. G., J.R. Chang, H. C. Cha, K. W. Lee, 1988. Plant Tissue Organ Cult., 12: 67-74.

17) Wehner, T. C., R. D. Locy, 1981. HortScience, 16: 759-760.

\title{
《和文要約》
}

メロンの茎, 本葉および茎頂組織からの不定胚形成拉よび植物体再生

\author{
景山幸二, 矢部和則, 宮島成壽 \\ 愛知県農業総合試験場 \\ 現在：岐阜大学農学部
}

メロン (Cucumis melo L.) の茎, 本葉, 茎頂からの不定胚形成掞よび植物体再生について検討した. 茎では, 生育の進んだ 3 品種の植物体の側枝を用い, $2,4-\mathrm{D}, \mathrm{NAA}$, 扔よびカザミノ酸濃度を変えた MS 培地で培養した. 品種により適する濃度に差が認められたが， 3 品種とも不定肧形成が認められた. 本葉では, 2 品種の無菌植物から材料を採取し，2,4-D およびしょ糖濃度を変えた MS 培地で培養した。 2 品種とあ不定胚形成が認められ，供試した 2,4-D 濃度による不定肧形成への影響は少なかったが, しょ糖濃度は $70 \mathrm{~g} / /$ が適していた。荃頂では, 11 品種の無菌植物から摘出した茎頂を $2,4-\mathrm{D}$ および しょ糖濃度を変えた MS 培地で培養した. 10 品種で不定胚が形成されたが, 不定胚形成能および最適培 地条件に品種間差が認められた。茎, 本葉执よび茎頂から誘導した不定胚は，ホルモンを含まないMS 培地で継代培養することにより植物体に再生した。 